\title{
Analyzing the Effect of the Product, Price Perception, and Promotion on Customer Loyalty to the Product of PT. EBARA Indonesia with Repurchase Intention
}

\author{
Andreas Natanael1 8 (D) $\square$ and Syafrizal Chan² 8 (D) \\ ${ }^{12}$ Universitas Mercubuana, Indonesia \\ $\triangle$ Corresponding Author: Andreas Natanael, E-mail: andreasnathan13@gmail.com
}

ARTICLE INFORMATION
Received: June 12, 2021
Accepted: July 28, 2021
Volume: 1
Issue: 1
DOI: $10.32996 /$ jbms.2021.3.2.6
KEYWORDS

Price perception, promotion, customer loyalty, repurchase intention

\section{ABSTRACT}

This study aimed to analyze the effect of the product, price perception, and promotion on customer loyalty to the product of PT. EBARA Indonesia with repurchase intention as an Intervening Variable. The number of research respondents was 137 respondents. The approach used in this research is quantitative. The data used in this study are primary data from the results of filling out the questionnaire. The data resulting from the filling was then analyzed through the Partial Least Square-Structural Equation Modeling (PLS-SEM) analysis technique with the help of the SmartPLS program. Following the results of the analysis, it can be concluded: (: (1) PT. EBARA Indonesia's products have a positive and significant effect on consumer repurchase intention with a coefficient; (2) The price perception of PT. EBARA Indonesia's products have a positive and significant effect on consumer repurchase intention; (3) Product promotion of PT. EBARA Indonesia has a positive and significant effect on consumer repurchase intention; (4) Repurchase intention products of PT. EBARA Indonesia has a positive and significant effect on consumer customer loyalty (5) Products of PT. EBARA Indonesia has a positive and insignificant effect on consumer customer loyalty ; (6) The price perception of PT. EBARA Indonesia's product has a positive and insignificant effect on consumer customer loyalty; (7) Product promotion of PT. EBARA Indonesia has a positive and insignificant effect on consumer customer loyalty; (8) PT. EBARA Indonesia's product has positive and negative effects. Significant impact on consumer customer loyalty through repurchase intention; (9) PT. EBARA Indonesia's product prices have a positive and significant effect on customer loyalty through consumer repurchase intention; (10) Promotion of PT. EBARA Indonesia has a positive and significant effect on customer loyalty through consumer repurchase intention.

\section{Introduction}

Competition for pump sales for industrial products is getting more challenging in line with the increasing number of similar products circulating in the market, both new products and existing products. This situation requires companies to make various efforts if they do not want to lose consumers to maintain their market share. Companies must understand well the behavior of consumers, namely selling and promoting goods or services with good quality and attractive services. If this can be implemented, the company will have the opportunity to gain greater profits than competitors.

Consumer behavior refers to the behavior seen by others how "consumers search for, buy, use, analyze and use without the rest of the goods and services that they hope will satisfy them" (Nitisusastro, 2012; Schiffman \& Kanuk, 2008). Related to purchasing decisions, the company understands things related to consumer behavior, namely, questions such as "what (what) to buy, where (where) to buy, how to buy (how often), and under what conditions (under what condition) all goods and all services purchased." An understanding of consumer behavior can be designed at the company according to what consumers want. Consumers play an

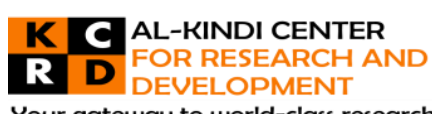

Your gateway to world-class research

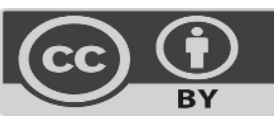

Published by Al-Kindi Center for Research and Development. Copyright (c) the author(s). This open access article is distributed under a Creative Commons Attribution (CC-BY) 4.0 license 
essential role for the company because, in the existence of products on the market, all company activities must have endeavored to target products so that customers can accept them.

The existence of needs that are not of the same type is then used as the basis for alternative products. In connection with the condition of consumers and customers with various types of needs, producers must respond in carrying out observations of what the customer wants.

The above phenomenon, the EBARA pump product, has been present in serving the needs of the world of construction and water treatment systems in Indonesia since 1980, which marked the establishment of PT. Ebara Indonesia in the form of a jointventure between PT. Donomulio Industri (Indonesia) and Ebara Corporation (Japan) having their addresses at the Jakarta-Bogor highway KM.32 Cimanggis, Java-West. The types of pumps produced by EBARA Indonesia manufacturers are clean water pumps, dirty water pumps, cooling pumps, to fire pumps/fire pumps.

With the work of EBARA pumps in high-rise building projects (malls, hotels, hospitals, office buildings, and apartments), agriculture, flood control, industrial pumps, be it light industry to heavy industry, this has created quite large unit sales every year. Year for the Indonesian market share. Where below the researcher only takes the number of unit sales in the last four years of EBARA pump sales which are shown in the graph below:

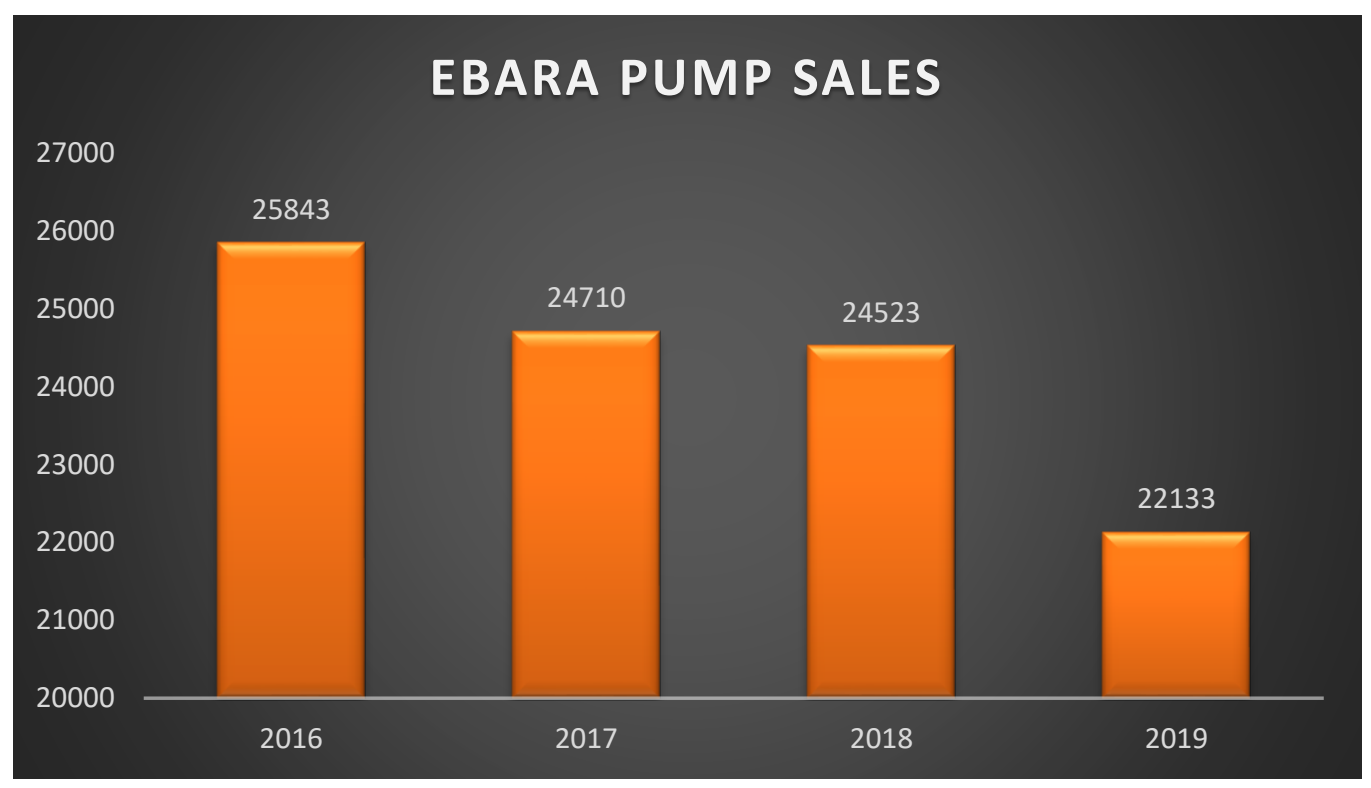

This decline in sales is an interesting phenomenon to study, considering that the competition for pumps for industrial products is getting tighter in line with the increasingly open pump engine market in Indonesia.

Sales fluctuations experienced by PT. EBARA Indonesia from each year in the 2016-2019 period illustrates that customer loyalty has a decreasing trend in buying these products. This is because many competitors have sprung up in pumps that display brands with quality and affordable prices that make pump users try these new products. The competitors include Thorisima, Teral, Grundfos, Willo, Dunamis, etc. brands. This situation makes an impact on the sales volume of a product. PT. EBARA Indonesia is also required to provide quality products and appropriate prices to attract customers to buy the products offered.

There are previous studies that have been done to find out what factors can affect customer loyalty. The factors that can affect customer loyalty in the scope of consumer behavior are Brand Image, Product Quality, Price Perception, Customer Satisfaction, Repurchase Interest (Savitri \& Wardana, 2018), Price, Product, Purchase Interest (Wirayanthy \& Santoso, 2018), Customer Loyalty, Promotion (Oluwafemi \& Adebiyi, 2018), Promotion, Price (Guissoni et al., 2018).

The marketing strategy is divided into several integrated marketing elements that are constantly evolving according to the development of the company and all changing marketing environments and changing consumer behavior. Consumer behavior has a widespread implementation in the formulation of marketing strategies. This event is because the marketing strategy is related 
to 2 main activities, namely selecting all marketing targets that will be used as markets and the formulation and preparation of an appropriate combination of the marketing mix so that what consumers need can be satisfied satisfactorily.

The results of product planning by the company must be based on what consumers need. Then, the results of the product must have the best quality. Because this is based on the company's vision and mission, where the products created are acceptable and based on what consumers need and can increase customer satisfaction. Because the product is the center of all marketing activities, a company's success can be seen from the response shown by consumers.

The demands on the company are also to increase and offer high-quality products compared to competitors by promoting sales so that there can be an increase in consumer buying interest in the products offered. The same thing is in line with (Ismajli et al., 2013), which states that "promotion is very influential on buying interest. The consumer's decision-making process in buying interest varies depending on the buying interest". Buying interest in a particular product is all very different things. Purchases that are expensive and complicated may result in many buyers considering and comparing with the purchase being not complicated and inexpensive (can be affordable by many consumers).

Low loyalty from customers is suspected, or there are indications of the consequences of uncompetitive products, low-quality products, uncompetitive prices, and lack of promotion, resulting in low buying interest. As a result, loyalty is also low. For that, this study will conduct in-depth research on PT. EBARA Indonesia.

This study aims to analyze the product, price perception, and promotion on customer loyalty to PT. EBARA Indonesia with repurchase interest as an Intervening Variable.

\section{Literature Review}

Consumer behavior. According to Schiffman and Kanuk (2008), consumer behavior is a behavior shown to consumers searching for, buying, using, evaluating, and disposing of products and services that they expect will satisfy their needs. Consumer behavior is a study of an engagement process when individuals or groups choose, buy, use or dispose of products, services, ideas, and experiences to satisfy their needs and wants.

Business to Business (B2B). The business market is the largest market of all business activities, exceeding the consumer market. The definition of a business market, according to Micheal Hutt and Thomas Speh in the book "Business Marketing Management: $\mathrm{B} 2 \mathrm{~B}$ " is a market for products and services, both local and international, where transactions are carried out between companies, governments, institutions that are used for the consumption of the company itself or resale. Markets that indirectly contribute to the business market directly transact on goods used for personal/individual use.

Customer Loyalty (Customer Loyalty). The commitment accompanied by repeated purchases is when consumers do not want to switch even though the product or service is challenging to find in the market, but consumers are willing to recommend the product or service to their friends, family, or other consumers. Based on the opinion of (Freddy Rangkuti, 2002), "Consumer loyalty is consumer loyalty to companies, brands, and products." Sutisna (2001) defines "loyalty as a favorable attitude towards a brand that is presented in a consistent purchase of that brand over time."

Repurchase Intention (Re-purchase Intention). Repurchase intention is the act of consumers to want to buy or not to the product (Philip Kotler et al., 2019). Purchase interest or consumer repurchase interest is closely related to consumers' motives to make a purchase or consume a particular product (Philip, 2012). The purchase motive is different for each consumer. If the product has attributes, is attractive and unique according to the level of need, then the product will be purchased by consumers. Repurchase (repurchase) can occur when making purchases made more than once.

Product (Product). According to Kotler \& Keller (2019), a product is "anything that can be offered to a market to satisfy a want or need, including physical goods, services, experiences, events, people, places, property, organizations, information, and ideas." According to Tjiptono (2014), a product is "everything that a producer can offer to be noticed, requested, sought, purchased, used, or consumed by the market to fulfill the needs or desires of the relevant market."

Price Perception (Price Perception). According to Schiffman and Kanuk (2008), price perception is the view or perception of how customers perceive a specific price (high, low, reasonable) that strongly influences purchase intention and purchase satisfaction. According to Rangkuti (2009), price perception is the relative cost that he must spend to obtain the product or service he wants. Furthermore, Rangkuti (2009) explains that price perception is measured based on the customer's perception by asking the customer what variables are most important in choosing a product. 
According to Monroe (2015), price perception is often identified with the perception of quality and the perception of the costs incurred to obtain the product.

Promotion (Promotion). Promotion is a factor that determines the success of marketing a product. Ongoh et al., (2015) argue that "promotion is a kind of communication that provides explanations and convinces potential consumers about goods and services intending to get attention, educating, reminding and convincing potential consumers." Another concept of promotion according to Kotler \& Armstrong (2014) is "company communication to consumers about products or services produced to build profitable relationships." Meanwhile, Kotler (2012) argues that "The promotion mix includes advertising (advertising), personal selling (personal selling), public relations (public relations) and publicity (publicity), sales promotion (sales promotion), and direct marketing (direct marketing). The promotional mix is part of the marketing stimulus, which is a variable that the company can control.

Model Framework. Based on the theory presented and studying previous research, the researchers arranged the interaction of the variables within the research framework as follows:

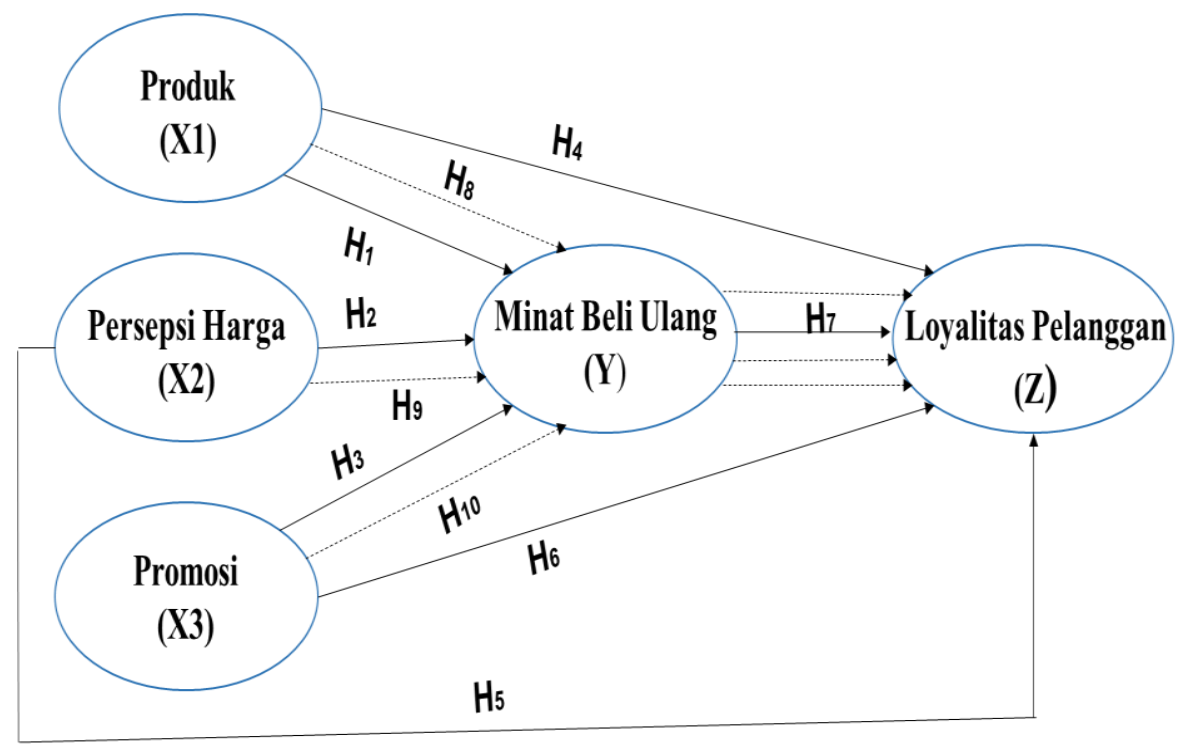

Figure 1: Model Framework

Based on some of the research model frameworks above, the hypotheses of this research are:

1. H1: PT. EBARA Indonesia has a positive and significant effect on the repurchase interest of customers who use / use (the better the brand product of PT. EBARA Indonesia, the higher the consumer's buying interest) ;

2. H2: Price Perception at PT. EBARA Indonesia has a positive and significant effect on the repurchase intention of customers who use / use (the more competitive the perception of the selling price of PT. EBARA Indonesia's products, the higher the consumer's request to repurchase) ;

3. H3: Promotion at PT. EBARA Indonesia has a positive and significant effect on the repurchase interest of customers who use / use (the more promotions on PT. EBARA Indonesia's products, the higher the consumer's request to repurchase) ;

4. H4: PT. EBARA Indonesia has a positive and significant effect on customer loyalty who uses/uses (the better the PT. EBARA Indonesia brand product, the higher consumer loyalty) ;

5. H5: Price Perception at PT. EBARA Indonesia has a positive and significant effect on customer loyalty who uses/uses (the more competitive the perception of the selling price of PT. EBARA Indonesia's products, the higher consumer loyalty) ;

6. H6: Promotion at PT. EBARA Indonesia has a positive and significant effect on customer loyalty who uses/uses (the more promotions on PT. EBARA Indonesia products, the higher consumer loyalty) ;

7. H7: Interest to repurchase at PT. EBARA Indonesia has a positive and significant effect on customer loyalty who uses/uses (the more buying interest in PT. EBARA Indonesia's products, the higher consumer loyalty) ;

8. H8: PT. EBARA Indonesia indirectly has a positive and significant effect on customer loyalty through repurchase interest ;

9. H9: Perceived price at PT. EBARA Indonesia indirectly has a positive and significant effect on customer loyalty through repurchase interest ; 
10. H10: Promotion at PT. EBARA Indonesia indirectly has a positive and significant effect on customer loyalty through repurchase interest.

\section{Methodology}

Research design. This research is included in causal research with a quantitative approach because it is carried out to determine whether there is an effect of the product, price, or promotion on customer loyalty with buying interest as an intervening variable. Population and Sample. The population that becomes the parameter of this research are customers who have always bought EBARA pump products (at least two times). Example: PT. Brantas (Persero), PT. PP (Persrero), PT. Adhi Karya (Persero), etc. The sampling technique is through non-probability sampling. So that the number of samples in this study was 123 respondents who were customers of EBARA pump products

Data collection. The technique of collecting data in this research is by making a questionnaire. The questionnaire used is a Likert scale 1-5 which shows à gradation of answers strongly disagree (STS) $=1$; Disagree $(\mathrm{TS})=2 ; \operatorname{Neutral}(\mathrm{N})=3 ;$ Agree $(\mathrm{S})=4$ and Strongly Agree (SS) $=5$.

Data Analysis Techniques. The data analysis of this research used descriptive analysis and Structural Equation Modeling (SEM) analysis, which was a multivariate analysis. Descriptive analysis of respondent characteristics and descriptive analysis of research variables were carried out with the help of the Microsoft Excel program, while PLS analysis was carried out with the help of Smart PLS ver three software.

\section{Results and Discussion}

\subsection{Results}

The results of the research data analysis that have been collected are then analyzed descriptively and quantitatively. Descriptive analysis is carried out using the Microsoft Excel program to see the description of product variables. In contrast, quantitative analysis is carried out through the Partial Least Square - Structural Equation Modeling (PLS-SEM) method to determine the effect of the product, price, and promotions variables on customer loyalty with purchase intention as an intervening variable.

\subsubsection{Characteristics of Respondents}

The number of respondents in this study was 137 people. Based on the gender characteristics of the respondents, most respondents were Male with a total of 94 people (68.60\%) and Female with a total of 43 people (31.40\%). Meanwhile, based on age characteristics, the majority of respondents were from the group aged $26-35$ years, as many as 83 people (60.60\%), while the lowest age group was from the age group > 55 years with six people (4.40\%). Meanwhile, based on the characteristics of the education status of the respondents, the most respondents were from the S1 education group with a total of 107 people (78.1\%), and the lowest was from D3 with a total of 6 people (4.4\%). Meanwhile, based on the respondent's position, most respondents were supervisors with 32 people (23.4\%), and with the minor position were directors as many as three people (2.2\%). Then the respondent with the most domicile in Jakarta is 86 people (62.80\%) and outside Jakarta is 45 people (37.2\%).

\subsubsection{Descriptive Analysis of Research Variables}

Descriptive data presents the general description related to the statements of 137 respondents to the questions in the questionnaire. By the responses from 137 respondents regarding the research, variables will be described in detail the respondents' answers which have been categorized in descriptive statistics. Empirical information on the data used in descriptive statistical research is through the use of average values so that it is known to what extent respondents' perceptions of the variables that are indicators in the study are known.

\subsubsection{Product Analysis (X1)}

The descriptive analysis of product variables shows consumer interest in EBARA pump products due to the various types/models of EBARA Pumps according to their designation, which makes consumers satisfied with the products of EBARA pumps.

\subsubsection{Analysis of Price Perception (X2)}

The descriptive analysis of price variables shows that consumers are interested in buying EBARA pumps because EBARA pumps have a competitive price perception and have benefits according to what consumers need. So there is no worry for consumers if they have bought an EBARA pump.

\subsubsection{Analysis of Promotion (X3)}

The results of the promotional descriptive analysis show that consumers of EBARA pumps, especially for their companies, do not feel worried for them after deciding to buy EBARA pumps with messages on promos that can be trusted. Because the EBARA pump is no longer sanctioned for the reliability of its products. 


\subsubsection{Analysis of Repurchase Interest $(Y)$}

The descriptive analysis of repurchase interest shows that consumers of EBARA pumps get good responses from customers regarding the product features of EBARA pumps. Thus customers will quickly find out the type of pump according to its application.

\subsubsection{Analysis of Customer Loyalty (Z)}

The results of the descriptive analysis of customer loyalty show that consumers of EBARA pumps get an excellent response to EBARA products, making consumers make repeated purchases to produce customer loyalty. Thus, customer loyalty to EBARA pump products increases.

\subsubsection{PLS-SEM analysis}

They tested this study's hypothesis using PLS-based SEM analysis techniques with the Smart PLS Version 3. Program. The stages of PLS analysis are the measurement model and the structural model. The data in the measurement model is evaluated to determine the level of validity and reliability.

Based on the measurement model test used in determining the specification of the relationship between latent variables and manifest variables, this test includes "Convergent validity, Construct Reliability, Average Variance Extracted-AVE, Discriminant validity, cross-loading and model unidimensionality." The following is the output result of the correlation between the indicator and Its construction is shown in the following figure and table :

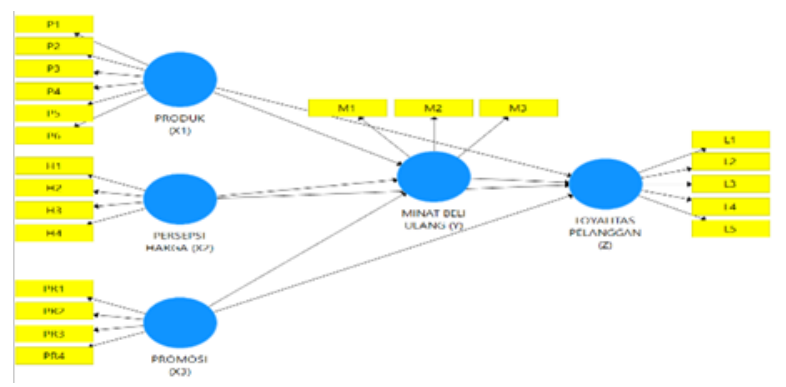

Figure 2: Outer model

\subsubsection{Outer Models}

Testing the structural model by looking at Convergent validity, Construct Reliability, Average Variance Extracted-AVE, Discriminant validity, cross-loading, and model unidimensionality.

Cronbach's Alpha, Composite Reliability \& AVE. Construct reliability is measuring the reliability of the latent variable construct. The value that is considered reliable must be above 0.70 . Construct reliability is the same as Cronbach alpha.

\subsubsection{Convergent Validity}

Convergent validity is used to determine the validity of each relationship between indicators and their latent constructs or variables. Convergent validity means that a set of indicators represents one latent variable and that underlies the latent variable.

\subsubsection{Discriminant Validity}

Discriminant validity aims to determine whether a reflective indicator is a good measure of its construct based on the principle that each indicator must be highly correlated with its construct only. Measures of different constructs should not be highly correlated (Ghozali, 2015). In the SmartPLS application, the discriminant validity test uses cross-loadings values and the FornellLarcker Criterion and Heterotrait-Monotrait (HTMT) (Henseler et al., 2015).

\subsubsection{Fornell-Larcker Criterion}

A construct is valid by comparing the root value of the AVE (Fornell-Larcker Criterion) with the correlation value between latent variables. The AVE root value must be greater than the correlation between latent variables.

Cross Loading

The cross-loading value of each construct was evaluated to ensure that the correlation of the construct with the measurement item was more significant than that of the other constructs. The expected cross-loading value is more significant than 0.7 (Ghozali, 2015). 


\subsubsection{Heterotrait-Monotriate Ratio Of Correlations (HTMT)}

Some experts argue that cross-loading and Fornell-Larcker Criterion are less sensitive in assessing discriminant validity. HTMT is a recommended alternative method to assess discriminant validity. This method uses a multitrait-multimethod matrix as the basis for measurement. The HTMT value should be less than 0.9 to ensure discriminant validity between the two reflective constructs (Henseler et al., 2015).

\subsubsection{VIF Outer}

The assumption or condition that must be met in the analysis of the outer model is that there is no multicollinearity problem. That is a problem where there is a strong intercorrelation or correlation between indicators. The limit is the correlation value $>0.9$, usually indicated by the Variance Inflating Factor (VIF) value at the indicator level > 5 .

\subsubsection{Structural Model Testing (Inner Model)}

The researcher tested the structural model by looking at the value of R2, Effect size f2, Predictive Relevance (Q-Square). The test results at this stage can be used to test the research hypothesis.

\subsubsection{Test Effect Size (f2)}

In addition to assessing whether or not there is a significant relationship between variables, researchers also assess the magnitude of the influence between effect size or $f$-square (Wong, 2013). The $f$ square value is 0.02 as petite, 0.15 as a medium, and 0.35 as large. Values less than 0.02 can be ignored or considered not to affect (J. F. Hair et al., 2011).

\subsubsection{R Square (R2)}

The value of $R$ Square is the coefficient of determination on the endogenous construct. According to Chin (1998), the value of $R$ square is 0.67 (strong), 0.33 (moderate) and 0.19 (weak).

Inner VIF. The VIF value must be less than five because if it is more than 5 , it indicates the existence of collinearity between constructs (J. Hair et al., 2017).

\subsubsection{Predictive Relevance (Q-Square) Value Test}

Predictive Relevance (Q-Square) > 0 (zero) indicates the model has a Predictive Relevance value, while the Q-Square value $<0$ (zero) indicates the model lacks Predictive Relevance. The results are based on the predictive relevance test (Q2) with a value of $0,87 \geq 0$ so that these results show that there are $87 \%$ variations in the variables.

\subsubsection{Hypothesis Testing Results (Estimated Path Coefficient)}

The estimated value of the path relationship in the structural model must be significant. The bootstrapping procedure can obtain significant values to see whether it is significant or not significant, as seen from the t-table at alpha $0.05(5 \%$ level) $=1.96$, then the t-table is compared with the T-statistics (calculation). The hypothesis test with the results obtained in the results of the bootstrapping report with SmartPLS.

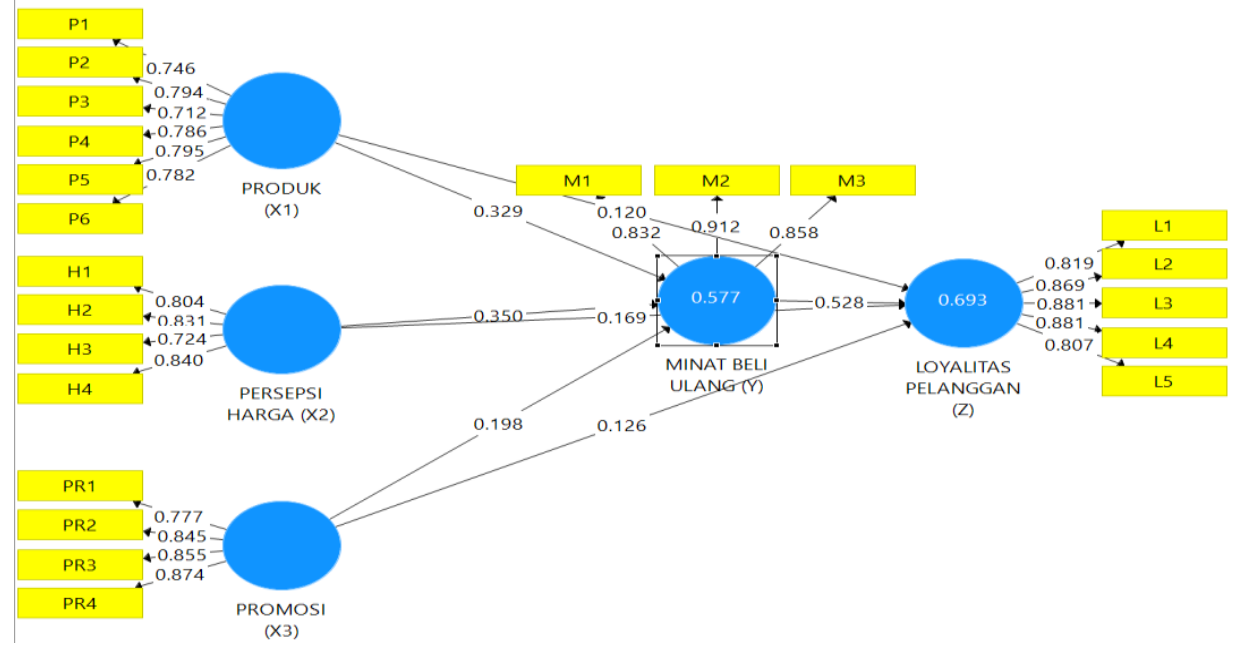

Figure 3: t-value test results 


\begin{tabular}{|c|c|c|c|}
\hline \multirow{2}{*}{ Hypothesis } & \multicolumn{3}{|l|}{ Result } \\
\hline & Coefficient & T Statistics & Conclusion \\
\hline $\begin{array}{l}\text { Product }(X 1) \rightarrow \text { Repurchase } \\
\text { Interest }(Y)\end{array}$ & 0.329 & 2.991 & $\begin{array}{l}\text { Accepted, positive and significant } \\
\text { effect }\end{array}$ \\
\hline $\begin{array}{l}\text { Price Perception (X2) } \rightarrow \\
\text { Repurchase Interest }(\mathrm{Y})\end{array}$ & 0.350 & 4.147 & $\begin{array}{l}\text { Accepted, positive and significant } \\
\text { effect }\end{array}$ \\
\hline $\begin{array}{ll}\text { Promotion } \quad(X 3) & \rightarrow \\
\text { Repurchase Interest }(Y) & \end{array}$ & 0.198 & 2.247 & $\begin{array}{l}\text { Accepted, positive and significant } \\
\text { effect }\end{array}$ \\
\hline $\begin{array}{l}\text { Product (X1) } \rightarrow \text { Customer } \\
\text { Loyalty }(Z)\end{array}$ & 0.120 & 1.475 & $\begin{array}{l}\text { Rejected, positive effect and not } \\
\text { significant }\end{array}$ \\
\hline $\begin{array}{l}\text { Price Perception (X2) } \rightarrow \\
\text { Customer Loyalty }(\mathrm{Z})\end{array}$ & 0.169 & 1.614 & $\begin{array}{l}\text { Rejected, positive effect and not } \\
\text { significant }\end{array}$ \\
\hline $\begin{array}{l}\text { Promotion }(\mathrm{X} 3) \rightarrow \text { Customer } \\
\text { Loyalty }(\mathrm{Z})\end{array}$ & 0.126 & 1.273 & $\begin{array}{l}\text { Rejected, positive effect and not } \\
\text { significant }\end{array}$ \\
\hline $\begin{array}{l}\text { Repurchase Interest }(\mathrm{Y}) \rightarrow \\
\text { Customer Loyalty }(\mathrm{Z})\end{array}$ & 0.528 & 6.698 & $\begin{array}{l}\text { Accepted, positive and significant } \\
\text { effect }\end{array}$ \\
\hline $\begin{array}{l}\text { Product }(\mathrm{X} 1) \rightarrow \text { Customer } \\
\text { Loyalty }(\mathrm{Z}) \rightarrow \text { Repurchase } \\
\text { Interest }(\mathrm{Y})\end{array}$ & 0.174 & 3.071 & $\begin{array}{l}\text { Accepted, positive and significant } \\
\text { effect }\end{array}$ \\
\hline $\begin{array}{lll}\text { Price Perception (X2) } & \rightarrow \\
\text { Customer Loyalty (Z) } & \rightarrow \\
\text { Repurchase Interest (Y) } & \end{array}$ & 0.185 & 3.102 & $\begin{array}{l}\text { Accepted, positive and significant } \\
\text { effect }\end{array}$ \\
\hline $\begin{array}{l}\text { Promotion (X3) } \rightarrow \text { Customer } \\
\text { Loyalty (Z) } \rightarrow \text { Repurchase } \\
\text { Interest }(Y)\end{array}$ & 0.105 & 1.920 & $\begin{array}{l}\text { Rejected, positive effect and not } \\
\text { significant }\end{array}$ \\
\hline
\end{tabular}

Explanation of the results of the hypothesis in Table 5.21, namely:

1. $\mathrm{H} 1$ is accepted because the T-statistic value shows $2,991>1.96$. The coefficient value of 0.329 means that the product has a positive and significant effect on repurchase interest.

2. $\mathrm{H} 2$ is accepted because the T-statistic value shows $4.147>1.96$. The coefficient value of 0.350 means that price perception has a positive and significant influence on repurchase interest.

3. $\mathrm{H} 3$ is accepted because the T-statistic value shows $2.247>1.96$. The coefficient value of 0.198 means that promotion has a positive and significant effect on repurchase interest.

4. $\mathrm{H} 4$ is rejected because the $\mathrm{T}$-statistic value shows $1.475<1.96$. The coefficient value of 0.120 means that the product has a positive and insignificant effect on customer loyalty.

5. H5 is rejected because the T-statistic value shows $1.614<1.96$. The coefficient value of 0.169 means that price perception has a positive and insignificant effect on customer loyalty.

6. $\mathrm{H} 6$ is rejected, because the T-statistic value shows $1.273<1.96$. The coefficient value of 0.126 means that promotion has a positive and insignificant effect on customer loyalty.

7. $\mathrm{H} 7$ is accepted because the T-statistic value shows $6.698>1.96$. The coefficient value of 0.528 means that repurchase interest has a positive and significant influence on customer loyalty.

8. $\mathrm{H} 8$ is accepted because the T-statistic value shows $3.71>1.96$. The coefficient value of 0.174 means that the product has a positive and significant influence on customer loyalty indirectly through repurchase interest as an intervening variable. 
9. $\mathrm{H} 9$ is accepted because the T-statistic value shows $3.102>1.96$. The coefficient value of 0.185 means that price has a positive and significant influence on customer loyalty indirectly through repurchase interest as an intervening variable.

10. $\mathrm{H} 10$ is accepted because the T-statistic value shows $1.920<1.96$. The coefficient value of 0.105 means that promotion has a positive and insignificant effect on customer loyalty indirectly through repurchase interest as an intervening variable.

\subsection{Discussion}

\subsubsection{The Effect of Products on Repurchase Interest}

Currently PT. EBARA Indonesia is required to offer a product that is of higher quality and has a higher value than other companies. EBARA pump is one of the factors that influence consumers in buying a product. PT. EBARA Indonesia must be able to think carefully about the quality of the EBARA Pump products offered by the company. Quality products are considered very important by consumers as a reference for decision-making in purchasing a product.

Based on the hypothesis test in this study, it is known that the product has a positive and significant effect on the repurchase intention of EBARA pump products. This is because it is known that the value of T-Statistic $=2,991>1.96$. A positive coefficient value of 0.329 means that the product variable $(\mathrm{X} 1)$ has a positive effect on repurchase interest (Y). Thus it can be concluded that the product has a positive and significant effect on repurchase intention.

Based on previous research conducted by Vivy Kristinae (2018), it was stated that the product had a significant effect on repurchase interest. This is in line with current research. Based on the research, it was found that the product factor was very influential when purchasing the EBARA pump. Business people must be more precise in carrying out development to the needs of their customers because a good product becomes a consideration or priority for business people towards product development. Thus, it can be concluded that the product variable is one of the factors that support customers in making repurchase intentions.

\subsubsection{The Influence of Price Perception on Repurchase Interest}

Price perception is how price information is fully understood and provides deep meaning for consumers. Price perception becomes an essential assessment for consumers about comparing the amount of sacrifice with what will be obtained from products and services.

Price perception is the view or perception of how customers perceive a specific price (high, low, reasonable) that strongly influences purchase intention and purchase satisfaction.

Consumers, before making a purchase, will take into account the quality of the product. Quality products can encourage consumers and increase consumer desire to have these products. With the quality by the wishes of consumers, companies can face market competition by this can create buying interest from consumers.

Based on the hypothesis test in this study, it is known that price perception has a positive and significant effect on the repurchase intention of EBARA pump products. This is because it is known that the value of T-Statistic $=4.147>1.96$. With a positive coefficient value of 0.350 , it means that the price perception variable (X2) has a positive effect on repurchase interest (Y). Thus, it can be concluded that price perception has a positive and significant effect on repurchase intention.

Based on previous research conducted by Cardia et al., (2019) stated that price perception significantly affects repurchase interest. This is in line with current research. Business people need to consider the perception of price according to the benefits of the product to support their request to repurchase. The price perception variable can affect repurchase interest because the perception of the price set by business actors is by customer needs. Therefore, the price perception variable becomes a priority for business people in increasing repurchase interest.

\subsubsection{The Effect of Promotion on Repurchase Interest}

Promotion is a controlled and integrated program of communication methods and materials designed to present the company and its products to potential customers, satisfying needs and driving sales, ultimately contributing to long-term profit performance. It can be seen that the promotion strategy is an activity that is planned to persuade, stimulating consumers to want to buy the company's products so that the goal of increasing sales is expected to be achieved.

Based on the hypothesis test in this study, it is known that promotion has a positive and significant effect on repurchasing interest in EBARA pump products. This is because it is known that the value of T-Statistic $=2.247>1.96$. With a positive coefficient value of 0.198 , it means that the promotion variable (X3) has a positive effect on repurchase interest (Y). Thus it can be concluded that promotion has a positive and significant effect on repurchase interest. 
Based on previous research conducted by Kansa Fadhilah (2016), the promotion significantly affected repurchase interest. This is in line with current research. Promotion is one of the supporting factors for repurchase interest because customers will consider the media as a customer supporting factor in determining repurchase interest in EBARA pump products. Thus, business people must pay attention to promotional factors in determining a customer's buying interest.

\subsubsection{The Effect of Products on Customer Loyalty}

Improving the quality of EBARA pump products is the company's way of increasing customer loyalty. This can be seen through products that are considered to have proven good by looking at the history of these products that are spread in the community, namely the ability and ability to help consumers and provide products according to regulations, even though they change product labels but consumers still choose the product because it has a good relationship. strong with the product. Minar \& Safitri (2017) suggests that factors must be considered to improve the quality of their products so that consumers believe in these products, which will eventually become loyal consumers.

Based on the hypothesis test in this study, it is known that the product has a positive and insignificant effect on customer loyalty for the EBARA pump product. This is because it is known that the value of T-Statistic $=1.475<1.96$. With a positive coefficient value of 0.120 , it means that the product variable (X1) has a positive effect on customer loyalty (Z). Thus it can be concluded that the product has a positive and insignificant effect on customer loyalty.

Based on previous research conducted by Altun et al., (2020), the product significantly affected customer loyalty. This is contrary to the research conducted at this time. Consumers will prioritize products with variants/appearances that attract customer buying interest to affect customer loyalty. Thus, business people must be precise in determining the product variants sold to market share by customer needs to create high customer loyalty.

\subsubsection{The Influence of Price Perception on Customer Loyalty}

Price perception is a thought/interpretation of consumers/customers on the amount of money used to get a desired product or service with a sacrifice value by what is obtained from the product or service. The perception of price is often identified with the perception of quality and the perception of the costs incurred to obtain the product.

Based on the hypothesis test in this study, it is known that price perception has a positive and insignificant effect on customer loyalty for EBARA pump products. This is because it is known that the value of T-Statistic $=1.614<1.96$. With a positive coefficient value of 0.169 , it means that the price perception variable (X2) has a positive effect on customer loyalty (Z). Thus it can be concluded that the price has a positive and insignificant effect on customer loyalty.

Based on previous research conducted by Yusuf Ihza Mahendra \& Dewi Harmin Sutanto (2021), stated that price perception has a significant effect on customer loyalty. This is contrary to the research conducted at this time. Price perception is often related to customer loyalty because customers tend to use the price factor as a potential element produced by the product on customer loyalty. Thus, it can be concluded that the price perception variable does not affect customer loyalty.

\subsubsection{The Effect of Promotion on Customer Loyalty}

Promotion is a factor that determines success in marketing a product. Ongoh et al., (2015)argue that promotion is a type of communication that provides explanations and convinces potential consumers about goods and services to get attention, educating, reminding, and convincing potential consumers. Promotion communicates information between sellers and potential buyers or other people to influence attitudes and behavior (Perreault et al., 2011).

Based on the hypothesis test in this study, it is known that promotion has a positive and insignificant effect on customer loyalty for EBARA pump products. This is because it is known that the value of T-Statistic $=1.273<1.96$. With a positive coefficient value of 0.126 , it means that the promotion variable (X3) has a positive effect on customer loyalty (Z). Thus it can be concluded that promotion has a positive and insignificant effect on customer loyalty. Based on previous research conducted by Anggitan (2013), the promotion significantly affects customer loyalty. This is contrary to the research conducted at this time. Customers tend to pay attention to promotional supporting factors as one of the triggers for customers to be loyal to products that have been purchased previously. Thus, business people must pay close attention to promotional variables in increasing customer loyalty.

\subsubsection{The Effect of Repurchase Interest on Customer Loyalty}

Buying interest is the stage of the respondent's tendency to act before the buying decision is implemented. There is a difference between actual purchase and purchase intention. If the actual purchase is a purchase made by the consumer, then purchase 
intention is the intention to purchase a future opportunity. Although it is a purchase that will not necessarily be made in the future, the measurement of purchase intention is generally carried out to maximize the prediction of the actual purchase itself.

Repurchase interest is purchase interest based on past purchase experiences. High repurchase interest reflects a high level of satisfaction from consumers when deciding to adopt a product. The decision to adopt or reject a product arises after consumers try a product, and then a feeling of liking or disliking the product arises. Love for the product arises when consumers have the perception that the products they use are of good quality and can meet or even exceed the wishes and expectations of consumers. In other words, the product has a high value in the eyes of consumers. This high repurchase interest will have a positive impact on the success of the product in the market.

Based on the hypothesis test in this study, it is known that repurchase interest has a positive and significant effect on customer loyalty for EBARA pump products. This is because it is known that the value of T-Statistic $=6.698>1.96$. With a positive coefficient value of 0.528 , the variable of repurchase interest $(Y)$ has a positive effect on customer loyalty $(Z)$. Thus, it can be concluded that repurchase interest has a positive and significant effect on customer loyalty.

Based on previous research conducted by Fitria Nur Srigati (2018), repurchase interest significantly affects customer loyalty. This is in line with current research. The variable of repurchase interest influences customer loyalty because customers will feel satisfied if their products are by customer needs and create high loyalty. Thus, it can be said that repurchase interest has a significant influence on customer loyalty.

\subsubsection{Indirect Effect of Products on Customer Loyalty through Repurchase Interest}

Customer loyalty shows the intended behavior related to products and services. This includes the likelihood of future purchases or renewal of service contracts or vice versa, how likely the customer will switch to another service provider or brand. Customers may become loyal because of high switching barriers related to technical, economic, and psychological factors that make it expensive or difficult for customers to change suppliers. Customers can also be loyal because they are satisfied with the supplier or product brand, its durability; the company tends to approach satisfaction as a potential strategy in the long term.

Based on the hypothesis test in this study, it is known that the product has a positive and significant effect on customer loyalty through repurchasing interest in EBARA pump products. This is because it is known that the value of T-Statistic $=3.071>1.96$. With a positive coefficient value of 0.174 , it means that the product variable $(X 1)$ has a positive effect on customer loyalty $(Z)$ through repurchase interest $(Y)$. Thus it can be concluded that the product has a positive and significant effect on customer loyalty through repurchase interest.

Based on previous research conducted by the product indirectly has a significant effect on customer loyalty through repurchase interest. According Noorhayati (2018), to the type variant, consumers will pay attention to the product that attracts customer interest in increasing repurchase interest and customer loyalty. The product variable has a significant influence on customer loyalty through repurchase interest. Thus, business actors must correctly determine the product variant of EBARA pumps according to market share needs to create customer loyalty.

\subsubsection{Indirect Effect of Price Perception on Customer Loyalty through Repurchase Interest}

The existence of prices can help buyers decide how to allocate their purchasing power to various goods and services. The buyer compares the prices of various available alternatives, then decides on the desired allocation of funds. Price is also one of the flexible elements of the marketing mix. Unlike product characteristics and distribution channel commitments, prices can change rapidly. At the same time, pricing and price competition are significant problems facing many marketing executives.

Based on the hypothesis test in this study, it is known that price perception has a positive and significant effect on customer loyalty through repurchasing interest in EBARA pump products. This is because it is known that the value of T-Statistic $=3.102>1.96$. With a positive coefficient value of 0.185 , it means that the price perception variable (X2) has a positive effect on customer loyalty (Z) through repurchase interest $(\mathrm{Y})$. Thus, it can be concluded that price perception has a positive and significant effect on customer loyalty through repurchase intention.

Previous research conducted by Intan Permata (2018) states that price perception indirectly has a significant effect on customer loyalty through repurchase interest. The product requires the customer to incur significant costs compared to the benefits received, then what will happen is that the product has a negative value. Conversely, if the customer perceives that the benefits received are more incredible, then what happens is that the product has a positive value. Thus, it can be concluded that price perception has a positive and significant influence on customer loyalty through repurchase interest. 


\subsubsection{Indirect Effect of Promotion on Customer Loyalty through Repurchase Interest}

According to Hermawan (2015), promotion is all activities intended to communicate or convey a product to the target market to provide information about its features, uses, and most importantly about its existence, to change attitudes or encourage people to act (in this case buy). Promotion is all activities intended to convey or communicate a product to the target market to provide information about the features of its use and, most notably about its existence to change attitudes or to encourage people to act or promotion is the main element in marketing campaigns. Promotion can be defined as a form of direct persuasion through the use of various incentives, generally short-term, which can be arranged to stimulate immediate product purchases or increase the number of goods purchased by customers or merchants.

Based on the hypothesis test in this study, it is known that promotion has a positive and significant effect on customer loyalty through repurchasing interest in EBARA pump products. This is because it is known that the value of T-Statistic $=1.920<1.96$. With a positive coefficient value of 0.105 , it means that the promotion variable (X3) has a positive effect on customer loyalty (Z) through repurchase interest $(Y)$. Thus it can be concluded that promotion has a positive and insignificant effect on customer loyalty through repurchase interest.

Based on previous research conducted by Yusuf Ihza Mahendra \& Dewi Harmin Sutanto (2021), it was stated that promotion indirectly had a significant effect on customer loyalty through repurchase interest. With good promotion and the benefits provided, the product will have a selling value that the customer considers meaningful. Business people have a relationship with the product and the perception of the price of a product. Thus, it can be concluded that promotion has a positive and significant influence on customer loyalty through repurchase interest.

\section{Conclusion}

The conclusion of this research is customer loyalty product PT. EBARA Indonesia is categorized as loyal. Interest in buying PT. EBARA Indonesia belongs to the high category. Products sold by PT. EBARA Indonesia is categorized as very good. Price Perception of PT. EBARA Indonesia is included in the expensive category, the promotion carried out by PT. EBARA Indonesia is in a good category. This can be seen from the relationship between variables as follows: (1) Products of PT. EBARA Indonesia has a positive and significant effect on consumer repurchase interest with a coefficient/parameter of 0.329 with T count $>\mathrm{T}$. table / 2,991 > 1.96; (2) Price Perception of PT. EBARA Indonesia has a positive and significant effect on consumer repurchase interest with a coefficient/parameter of 0.350 with T count $>$ T. table / $4.1472>1.96$; (3) Promotion of PT. EBARA Indonesia has a positive and significant effect on consumer repurchase interest with a coefficient / parameter of 0.198 with T count $>$ T. table / $2.247>1.96$; (4) PT. EBARA Indonesia has a positive and insignificant effect on consumer customer loyalty with a coefficient/parameter of 0.120 with T count < T. table / $1.475<1.96$; (5) Perception of the price of PT. EBARA Indonesia has a positive and insignificant effect on consumer customer loyalty with a coefficient/parameter of 0.169 with T count $<$ T. table / $1.614<1.96$; (6) Promotion of PT. EBARA Indonesia has a positive and insignificant effect on consumer customer loyalty with a coefficient/parameter of 0.126 with $T$ count $<$ T. table / $1.273<1.96 ;(7)$ Interest in Repurchase of PT. EBARA Indonesia has a positive and significant effect on consumer customer loyalty with a coefficient / parameter of 0.528 with T count > T. table / 6,698 > 1.96; (8) PT. EBARA Indonesia has a positive and significant effect on consumer customer loyalty through repurchase interest with a coefficient/parameter of 0.174 with T count > T. table / 3,071 > 1.96; (9) Perception of PT. EBARA Indonesia has a positive and significant effect on customer loyalty through consumer repurchase interest with a coefficient/parameter of 0.185 with T count $>\mathrm{T}$. table / $3.102>1.96 ;(10)$ Promotion of PT. EBARA Indonesia has a positive and insignificant effect on customer loyalty through consumer repurchase interest with a coefficient/parameter of 0.105 with T count $<$ T. table / $1.920<1.96$.

Funding: "This research received no external funding"

Acknowledgments:

Conflicts of Interest: "The authors declare no conflict of interest."

\section{References}

[1] Altun, A., Basri, M., \& Abdullah, A. (2020). Pengaruh Kualitas Produk dan Harga Terhadap Loyalitas Konsumen Pada Surya Swalayan Kendari. Business UHO: Jurnal Administrasi Bisnis, 5(1), 228-236. https://doi.org/http://dx.doi.org/10.52423/bujab.v5i1.12632

[2] Cardia, D. I. N. R., Santika, I. W., \& Respati, N. N. R. (2019). PENGARUH KUALITAS PRODUK, HARGA, DAN PROMOSI TERHADAP LOYALITAS PELANGGAN. E-Jurnal Manajemen Universitas Udayana, 8(11), 6762. https://doi.org/10.24843/EJMUNUD.2019.v08.i11.p19

[3] Chin, W. W. (1998). The partial least squares approach for structural equation modeling. In Modern methods for business research. (pp. 295336). Lawrence Erlbaum Associates Publishers.

[4] Fadhilah, K. (2016). Pengaruh Harga, Kualitas Produk, Dan Promosi Terhadap Keputusan Pembelian Yang Berdampak Pada Loyalitas (Studi Pada Konsumen Lipstik Wardah di Semarang). Universitas Dian Nuswantoro.

[5] Ghozali, H. I. (2015). Partial Least Squares: Konsep, Teknik dan Aplikasi Menggunakan Program SmartPLS 3.0 Untuk Penelitian Empiris. Badan Penerbit Universitas Diponegoro. 
[6] Guissoni, L. A., Sanchez, J. M., \& Rodrigues, J. M. (2018). Price and in-store promotions in an emerging market. Marketing Intelligence \& Planning, 36(4), 498-511. https://doi.org/10.1108/MIP-08-2017-0154

[7] Hair, J. F., Ringle, C. M., \& Sarstedt, M. (2011). PLS-SEM: Indeed a silver bullet. Journal of Marketing Theory and Practice, 19(2), 139-152. https://doi.org/10.2753/MTP1069-6679190202

[8] Hair, J., Hult, G. T., Ringle, C., \& Sarstedt, M. (2017). A Primer on Partial Least Squares Structural Equation Modeling (PLS-SEM) - Joseph F. Hair, Jr., G. Tomas M. Hult, Christian Ringle, Marko Sarstedt. In Sage.

[9] Henseler, J., Ringle, C. M., \& Sarstedt, M. (2015). A new criterion for assessing discriminant validity in variance-based structural equation modeling. Journal of the Academy of Marketing Science, 43(1), 115-135. https://doi.org/10.1007/s11747-014-0403-8

[10] Ismajli, A., Kajtazi, S., \& Fejza, E. (2013). The Impact Of Promotional Activities On Purchase Decision Making: A Case Study Of Brand Bonita And Rugove-Water Bottled Producers. European Scientific Journal, ESJ, 9(31). https://doi.org/ttps://doi.org/10.19044/esj.2013.v9n31p\%p

[11] Kotler, P., \& Armstrong, G. (2014). Prinsip-Prinsip Pemasaran. Erlangga.

[12] Kotler, K. L., Brady, M., Goodman, M., \& Hansen, T. (2019). Marketing management.

[13] Kristinae, V. (2018). Pengaruh Produk, Harga dan Promosi Terhadap Minat Konsumen Untuk Melakukan Pembelian Kerajinan Tangan Rotan. Eksis: Jurnal Riset Ekonomi Dan Bisnis, 13(1), 25-30. https://doi.org/10.26533/eksis.v13i1.154

[14] Minar, D., \& Safitri, A. (2017). Brand Image and Product Quality on Customer Loyalty (Survey in Cekeran Midun). TRIKONOMIKA, 16(1), 43. https://doi.org/10.23969/trikonomika.v16i1.420

[15] Monroe, M. C., \& Krasny, M. E. (2015). Cross the Spectrum: Resources for Environmental Educators, Third Edition (2016). North American Association for Environmental Education.

[16] Nitisusastro, M. (2012). Perilaku Konsumen Dalam Perspektif Kewirausahaan. Alfabeta.

[17] Oluwafemi, O. J., \& Adebiyi, S. O. (2018). Customer Loyalty and Integrated Marketing Communications among Subscribers of Telecommunication Firms in Lagos Metropolis, Nigeria. Journal of Competitiveness, 10(3), 101-118. https://doi.org/10.7441/joc.2018.03.07

[18] Ongoh, D. G., Mandey, S. L., \& Jorie, R. J. (2015). Analisis Strategi Promosi dan Harga Pengaruhnya Terhadap Keputusan Pembelian Mobil Suzuki Ertiga Pada Pt. Sinar Galesong Pratama Manado. Jurnal Riset Ekonomi, Manajemen, Bisnis Dan Akuntansi, 3(3). https://doi.org/https://doi.org/10.35794/emba.3.3.2015.9496

[19] Perreault, W. D., McCarthy, E. J., \& Cannon, J. P. (2011). Basic marketing: a global-managerial approach. McGraw-Hill.

[20] Philip, K. (2012). Strategic Brand Management: Building, Measuring, and Managing Brand Equity. Prentice Hall inc.

[21] Rangkuti, F. (2009). Strategi Promosi yang Kreatif dan Analisis Kasus Integrated Marketing Communication. PT Gramedia Pustaka Utama. https://books.google.co.id/books?id=9CYQSHfgg7kC

[22] Rangkuti, F. (2002). Measuring customer satisfaction: teknik mengukur dan strategi meningkatkan kepuasan pelanggan plus analisis kasus PLN-JP. Gramedia Pustaka Utama.

[23] Savitri, I. A. P. D., \& Wardana, I. M. (2018). PENGARUH CITRA MEREK, KUALITAS PRODUK DAN PERSEPSI HARGA TERHADAP KEPUASAN DAN NIAT BELI ULANG. E-Jurnal Manajemen Universitas Udayana, 7(10), 5748. https://doi.org/10.24843/EJMUNUD.2018.v07.i10.p19

[24] Schiffman, L. G., \& Kanuk, L. L. (2008). Perilaku konsumen. Jakarta: Indeks. http://opac.library.um.ac.id/oaipmh/../index.php?s_data=bp_buku\&s_field=0\&mod=b\&cat=3\&id=53339

[25] Sutisna K, \& Rakhmat, M. F. (2001). Perilaku konsumen \& komunikasi pemasaran. PT Remaja Rosdakarya.

[26] Tjiptono, F. (2014). Pemasaran Jasa: Prinsip, Penerapan, Penelitian. Andi.

[27] Wirayanthy, N., \& Santoso, S. (2018). Pengaruh Harga, Citra Merek Dan Kualitas Terhadap Minat Beli Produk Private Label. JMD: Jurnal Riset Manajemen \& Bisnis Dewantara, 1(2), 87-96. https://doi.org/10.26533/jmd.v1i2.231

[28] Wong, K. (2013). Partial least square structural equation modeling (PLS-SEM) techniques using SmartPLS. Marketing Bulletin, $24,1-32$.

[29] Yusuf I. M., \& Dewi H. S. (2021). IMPLEMENTASI METODE HEAR THEM OUT, EMPATHIZE, APOLOGIZE DAN TAKING PROPER ACTION AND FOLLOW UP (HEAD) SEBAGAI PELAYANAN PRIMA BISNIS PERHOTELAN. Journal of Islamic Science, Culture \&amp; Social Studies, 1 (1 SEArticles), 81-91. https://journal.ascarya.or.id/index.php/iscs/article/view/11 